\title{
Organizational Culture Transformation Model: Towards a High Performance Organization
}

\author{
Asier Ipinazar ${ }^{1}(\mathbb{D})$, Enara Zarrabeitia ${ }^{1}$ (D) Rosa Maria Rio Belver ${ }^{2}$ (D), Itziar Martinez-de-Alegría ${ }^{1}$ (D) \\ ${ }^{1}$ Industrial Organization and Management Engineering Department. Faculty of Engineering in Bilbao. \\ University of the Basque Country (UPV/EHU) (Spain) \\ ${ }^{2}$ Industrial Organization and Management Engineering Department. Faculty of Engineering in Vitoria-Gasteiz: \\ University of the Basque Country (UPV/EHU) (Spain) \\ asier.ipinazar@gmail.com, enara.zarrabeitia@ehu.eus,rosamaria.rio@ebu.eus, itziar.martinezdealegria@ebu.eus
}

Received: August 2020

Accepted: November 2020

\section{Abstract:}

Purpose: The main objective of this research is to design an Organizational Culture Transformation Model (OCTM) prototype, in order to enable a High Performance Organization (HPO).

Design/methodology/approach: There are three main processes involved in the methodology. Two of them, the definition of the main OCTM work elements as an initial hypothesis based on a work environment approach and the scientific visualization of the key Organizational Culture research hubs through the analysis of the main topics in research publications, flow in parallel. Subsequently, at a certain point, both of these merges in a third process, the OCTM prototype definition. This last process, will deliver the Organizational Culture Transformation Model prototype, which essentially constitutes the main objective of the study.

Findings: As result of the methodology, an Organizational Culture Transformation Model prototype has been developed.

Originality/value: The resulting model will serve as a reference framework for those companies that wish to conduct an in-depth re-structuring of their operations, focusing it on their human capital.

Keywords: organizational culture, high performance organization, organizational culture transformation model, manufacturing industry

\section{To cite this article:}

Ipinazar, A., Zarrabeitia, E., Rio Belver, R., \& Martinez-de-Alegría, I. (2021). Organizational Culture

Transformation Model: Towards a High Performance Organization. Journal of Industrial Engineering and Management, 14(1), 25-44. https://doi.org/10.3926/jiem.3288

\section{Importance of Organizational Culture as a Differentiating Factor in Industry}

The rapid globalization of markets, the impact of emerging markets such as Eastern European countries, India or China and especially the Great Recession of 2008 have resulted in an increasingly competitive, dynamic and 
aggressive new environment which tests the ability to act and react of those who wish to operate within it (Felipe, Roldán \& Leal-Rodríguez, 2017;Sandoval, 2014).

This new reality has produced, to a greater or lesser degree, a paradigm shift for companies all over the world, being especially critical for those who wish to continue operating globally from any non-emerging country, where existing salaries make it very difficult to compete with the low costs of other countries with lower salary costs.

For those companies, it is no longer enough to be efficient (proper resource management) or effective (results based focus), but to be innovative by imagining new perspectives such as the management of the human capital, being necessarily understood as key factor and offering a potentially strong competitive advantage (Bortolotti, Boscari \& Danese 2015).

Whenever a job is threatened, the well-being of workers becomes more critical, as it could favor a sustainable development of organizations and to focus on the promotion and development of employees and well-being at the individual and organizational level could contribute towards workers and organizations (Di Fabio \& Peiró, 2018), providing a competitive advantage to face the crisis environments (Azanza \& Moriano, 2013).

The need to manage such a resource as powerful as human capital will inexorably compel organizations to set out on the path to High Performance Organization (HPO), where the capabilities of each individual within the organization are respected and developed, there is a productive use of diversity and operations are always principle based. Furthermore, a clear vision exists and 100\% of the organization is engaged and committed to achieving such, always working as a team, so they are continuously improving through a Zero Loss Mindset (Waal, 2008) and to this end, it is necessary to extend the range of action to more intangible aspects such as Organizational Culture.

Due to its influence over the way employees think, act, and respond (Lee, Shiue \& Chen, 2016) and consequently, its ability to create an environment that would impact on both business and operational performance (Valmohammadi \& Roshanzamir, 2015), the handling of Culture in Organizational theory discipline giving rise to Organizational Culture, has become a field of interest and the object of study for many authors in recent years (Belias, Koustelios, Vairaktarakis \& Sdrolias, 2015; Bortolotti et al., 2015; Cújar, Ramos, Hernández \& López, 2013).

Nowadays, the most widespread and accepted definition is the one given by Edgar Schein in 1983 in his work "Organizational Culture and Leadership", where the author defines Organizational Culture as "A pattern of shared basic assumptions that was learned by a group as it solved its problems of external adaptation and internal integration, that has worked well enough to be considered valid and, therefore, to be taught to new members as the correct way to perceive, think, and feel in relation to those problems" (Schein, 2004).

Equivalent to the identity of an individual (Chávez \& Ibarra, 2016), Organizational Culture is unique to each organization and has a direct impact on vital success variables such as financial aspects, staff satisfaction, operational effectiveness and commitment (Abdullah, Shamsuddin, Wahab \& Hamid, 2014; Hartnell, Ou \& Kinicki, 2011). By evaluating Organizational Culture, it is possible to determine what kind of difficulties exist within an organization at human and organizational resources level, both internal and external, which facilitate or diffuse the processes that will steer productivity of members of organizations (Maish, 2004).

To implement Organizational Culture, it is necessary to influence the behavior and attitudes of the members of these organizations, through models appropriate to their objectives, beliefs and capabilities (Chávez \& Ibarra, 2016). However, the construction of an Organizational Culture is never instantaneous (Contreras \& Gómez, 2018) nor is it a simple, short-term task; on the contrary, it is complex, mid to long-term one.

Therefore, the culture of an organization is not changed on a whim or a fad, there has to be a sound reason which, in the most extreme case as explained previously, could be the survival of the business: change the Organizational Culture or simply disappear (Iljins, Skvarciany \& Gaile-Sarkane, 2015).

In this context, the main objective of this research is to define a prototype of an Organizational Culture Transformation Model (OCTM) for a company located in Bizkaia (Basque Country, Spain), as reference and example for those companies that wish to implement a deep transformation of their Organizational Culture, in order to create a new HPO environment. 


\section{Context of the Research}

Founded in 1931, the company where the research has been developed produces products for the automotive market, being the world's largest manufacturer within its sector since 1988. Figure 1 represents market share by companies. For reasons of confidentiality just figures are shown.

With over 143,000 employees worldwide across 150 countries, in 163 manufacturing plants and 6 Research \& Development centers, local and global performance makes possible to produce a range of different products mainly for the automotive market, representing the main business of the company. Figure 2 represents the distribution between automotive market and non-automotive market products.

(15.7\%) Market share of the company where the research has been developed

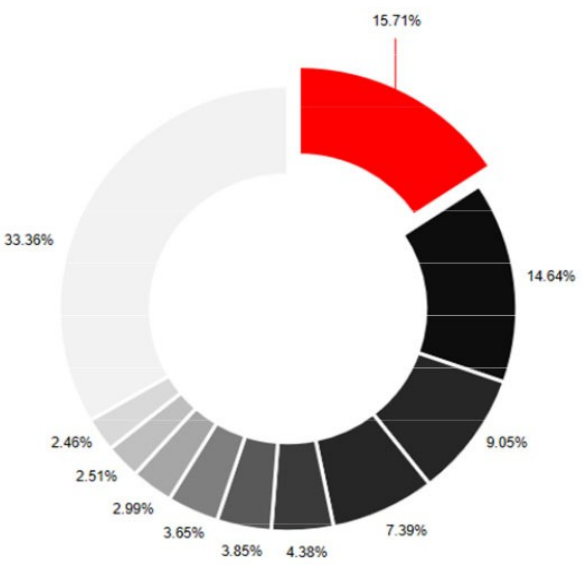

Figure 1. Market share 2019 (Company of study, 2019)

\section{(16.7\%) Non-automotive market products}

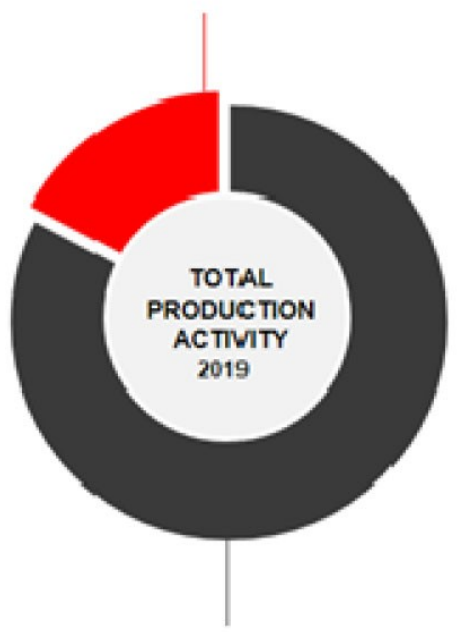

(83.3\%) Automotive market products

Figure 2. Product distribution (Company of study, 2019)

The manufacturing plant in Bizkaia, location where the study has been conducted, was founded in 1933 becoming one of the group's seventeen EMIA (Europe, Middle East, India and Africa) manufacturing plants in 
1988, when the present company took control of the original one. Figure 3 represents the company's EMIA presence.

Covering an area of $105,000 \mathrm{~m}^{2}$, over 750 employees produce products solely for the automotive market in a portfolio of different brands.

Throughout its long history, within the group, the plant has been renowned for the high quality of its products, and good business performance, enabling it be competitive even from a location where salaries are higher than other parts of the world such as Eastern European countries, India or China.

However, this trend radically changed with the great recession of 2008-2014, a period during which, in line with the rest of the overall economy, sales plummeted creating an unsustainable situation for the plant.

So much so that in 2015 the plant had no choice but reinvent itself as a means of survival. In this context, the plant's senior management realized that the only choice to survive was to reinforce human capital and to make this the basis of the activity, thus, they took the decision to produce a model to transform the plant's current culture in order to make this possible.

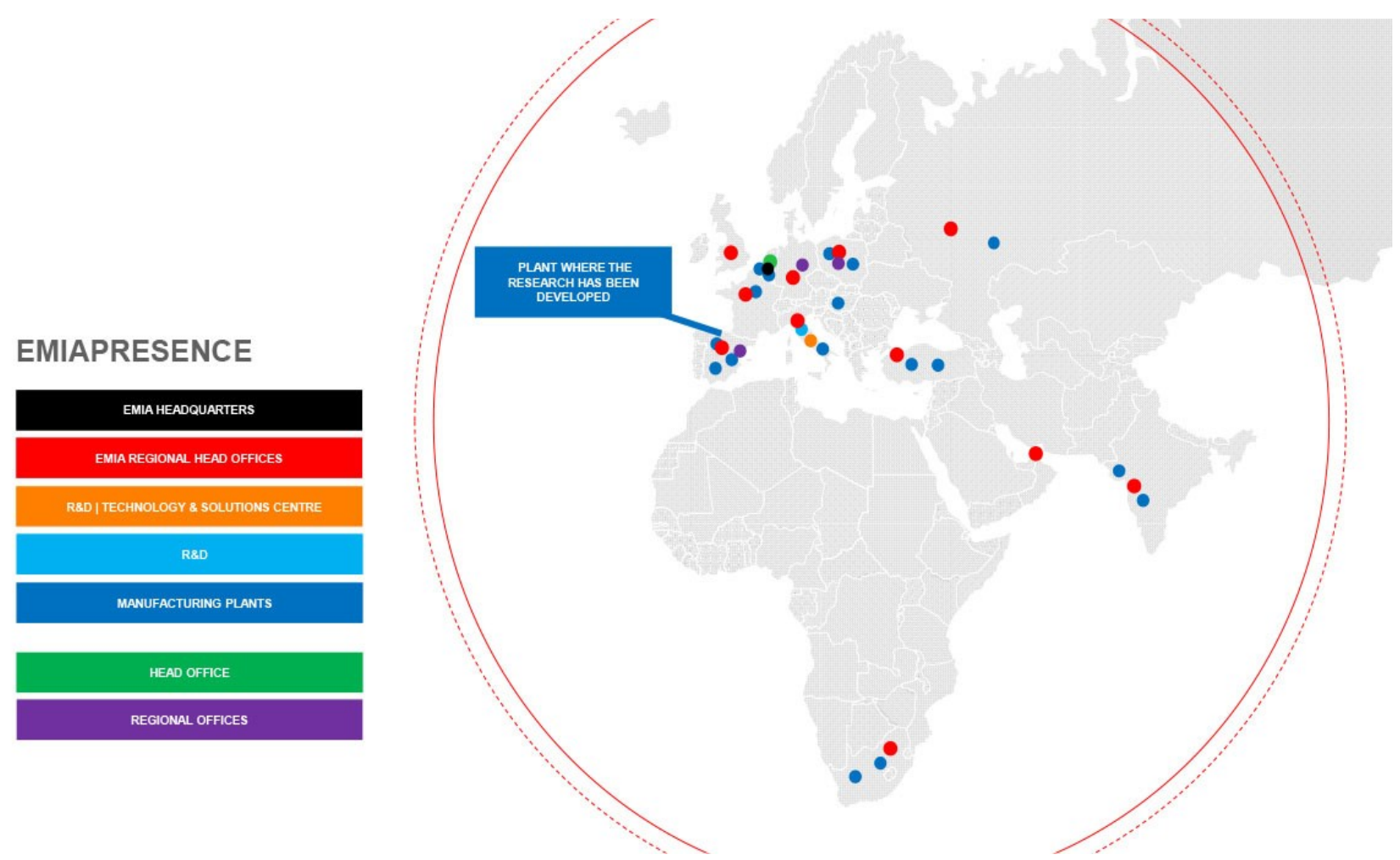

Figure 3. EMIA presence (Company of study, 2019)

\section{Research Methodology}

The procedure followed to achieve these research objectives consists of three main processes. Two of them (Work Element Definition and Scientific Visualization) flow in parallel and, at certain point, both of these merges in a third process (OCTM prototype definition). The latter delivering the OCTM Prototype, which essentially constitutes the main objective of the study.

Figure 4 represents the workflow followed in the research. 


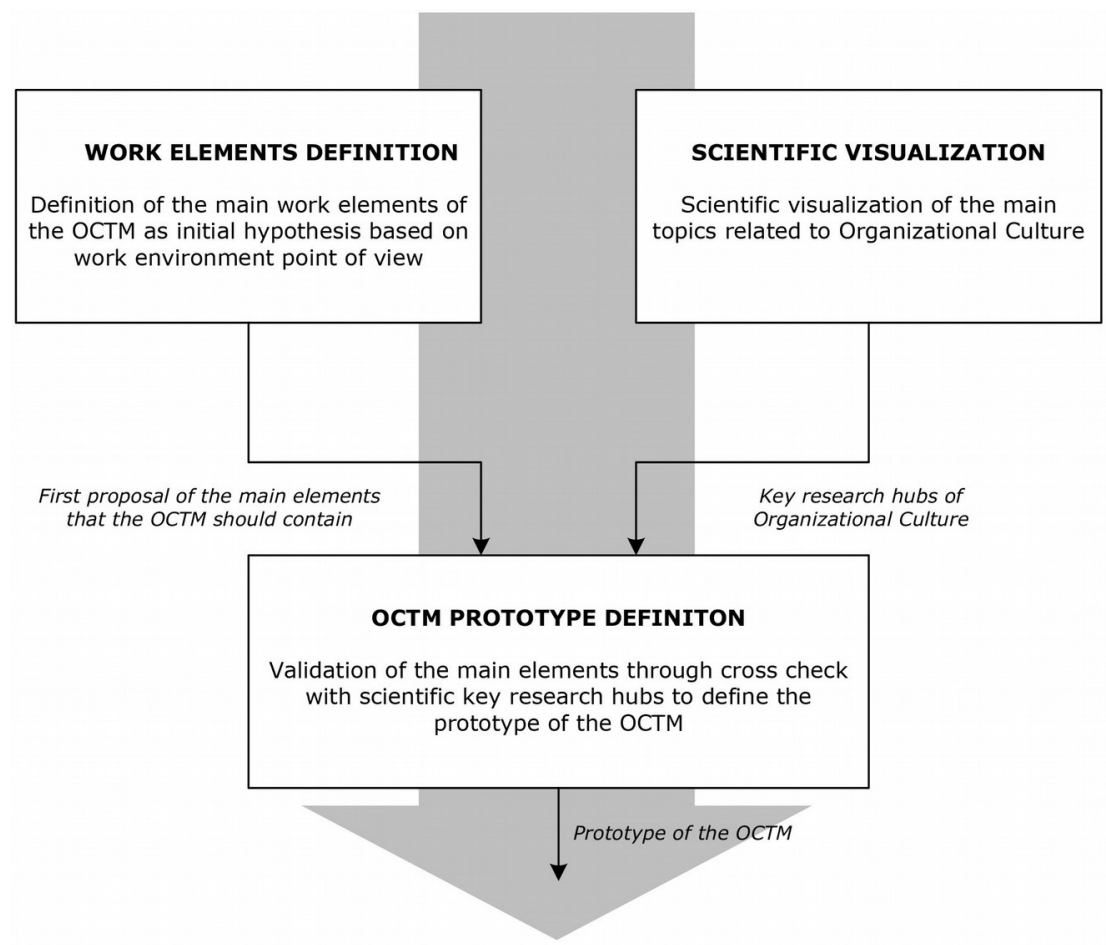

Figure 4. Main workflow of the research

A detailed explanation of each process is given below.

Work Element Definiton: Definition of the main OCTM work elements as an initial hypothesis based on work environment point of view.

This process consists of three steps, as shown in the Figure 5 and described later.

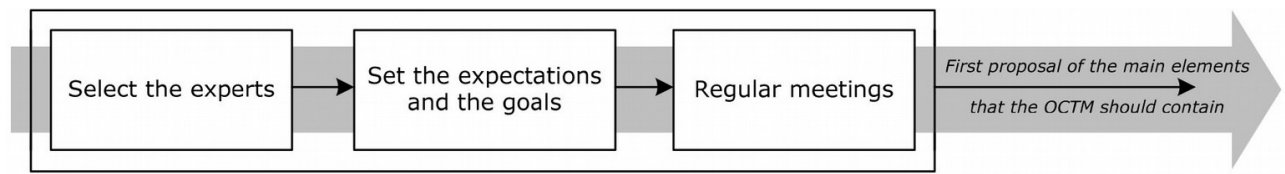

Figure 5. Workflow of Work Element Definition process

In order to minimize biases and conflicts of interests (Capacity4dev, 2015), the assistance of experts has been employed during this process. These experts have been selected based on their reputable experience in different knowledge hubs closely related with the transformation of the organizations and the concept of HPO and they are differentiable in two groups:

- Experts of the company itself: Senior Management members and Human Resources department staff with a thorough understanding of process management, leadership in industrial environments and optimization of organizational efficiency.

- External consultants: Reputable specialists with extensive experience in change management and the transformation of the organizations through the implementation of initiatives which facilitate the evolution of companies toward HPO.

A seven-member team was set up to support research through regular meetings, proposing the main elements that an OCTM should contain. Three of the seven members are from the company and the remaining four are from two independent consultancy companies. 
Both companies are a reference of operational excellence, with one of the two consultancy companies specializing in creating open communication spaces within teams, where team members developed all their interaction skills to promote and make the organizational changes sustainable. To this end, this company has its own model based on a neuro learning methodology applied to leadership, focused on the "soft" part of change management.

The second consultancy company is known for its own tool-and-system based model, which enables companies to make organizational changes. This model, unlike the other, impacts on the "hard" part of change management, creating a servant leadership environment and continuous development of people as facilitators of continuous improvement.

The reason for selecting these two consultancy companies lies precisely in their own models and in the possibility of merging both in order to create a customized model to meet the needs of the company and, if successful, replicable for other companies in a similar situation.

Once the consultancy companies had been selected and the team members appointed, the team prepared a regular meeting agenda with the following steps:

- Consultants from each consultancy company explained their respective models.

- Guided by the internal experts, discussion session processes were implemented in order to define the main elements of the OCTM prototype.

Scientific Visualization: Scientific visualization of the key Organizational Culture research hubs through analysis of the main topics in research publications.

This process had its own four-step workflow, as shown in Figure 6.

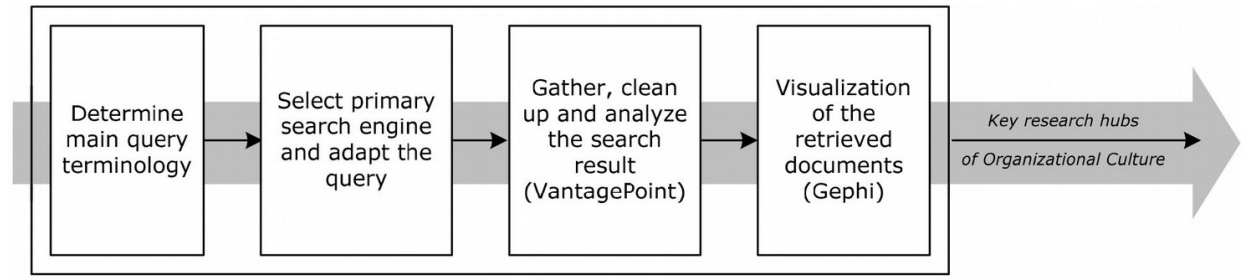

Figure 6. Workflow of Scientific Visualization process

The first step in this process has been an initial deep review of the relevant documents in order to determine main query terminology related with the subject matter. During this part of the process, the research has also been supported by the experts. Through the review, it has been concluded that "Organizational Culture" in all its terminological variants satisfies the requirements of the research, fully covering the range of the subject matter.

Once the query terminology has been fixed, the next step has been to select the primary search engine and to adapt the query to the selected database. Regarding the selection of the scientific database, several studies show that better results are obtained by using one of these primary search engines: Scopus, Web of Science (WoS) or Google Scholar (GS). Nevertheless, a very high percentage of WoS and Scopus citations are normally found in GS; those that are not, called unique citations, present a lower scientific impact than WoS and Scopus citations. Furthermore, the two databases complement each other (Alvarez-Meaza, Zarrabeitia-Bilbao, Rio-Belver \& Garechana-Anacabe, 2020). Taking into account the reliability of Scopus, which is one of largest abstract and citation databases of peer-reviewed literature with 75 million documents indexed (Elsevier, 2019), the selected database has been Scopus.

To adapt the query to Scopus, the search has been focused on author keywords, as these are specified by the authors as core concepts and being subject limited to Management Science (Business, Management, Accounting, Social Sciences, Decision Sciences, Economics, Econometrics and Finance), knowing that those areas are the ones where scientific community production is more aligned with the research, since it orients transformation of the organization towards HPO.

Table 1 represents the query terminology, adapted to selected database (Scopus). 


\section{Query}

AUTHKEY ("organi?ation* cultur*") AND (LIMIT-TO (SUBJAREA,"BUSI") OR LIMIT-TO (SUBJAREA, "SOCI") OR LIMIT-TO (SUBJAREA, "DECI") OR LIMIT-TO (SUBJAREA, "ECON")

Table 1. Query terminology adapted to the Scopus database

The search results have been imported to VantagePoint (VP) software in order to clean up and analyze the documents. VP works with search results from text databases and its capabilities can be broad after importing raw data from scientific databases and includes powerful data cleaning tools (VantagePoint, 2019). VP had made fuzzy matching possible in order to group the variations of a word (plurals, acronyms, and similar expressions, among others) that convey the same meaning.

As final step and to facilitate the analysis, a visualization of networks has been carried out, visualizing Author Keyword co-occurrences, using Gephi software, which allows large networks to be displayed in real time, enabling work with complex data sets to produce valuable visual results (Bastian, Heimann \& Jacomy, 2009; Gephi, 2019).

At the end of this scientific visualization process, the outcome has been a clear definition of the current key research hubs of Organizational Culture which has been visualized in a network map (authors' keyword co-occurrence for documents from 2015 to 2020) during subsequent process and used to compare with and to validate defined main work elements of the OCTM. Additionally, to reinforce the research, a deep review of the most relevant documents related with the case of study has been carried out.

The documents to be revised have been selected based on their impact, measured in number of citations. In order to gather the latest trends in the area of Organizational Culture and to minimize temporality impact (older documents had more time to be cited), the search has been limited to the period from 2015 to 2020 .

OCTM Prototype Definition: Validation of the first proposal of the main conceptual elements that the OCTM should contain through crosschecking with the key research hubs of Organizational Culture, in order to fix the key work elements and create with them the OCTM prototype.

Through a crosscheck between the outputs of the previous two processes, the main working concepts that the OCTM has to develop have been defined as concepts, and have been used to generate the OCTM prototype as a multilayer model with nucleus, design elements, performing elements and tools. Figure 7 represents the workflow of this process.

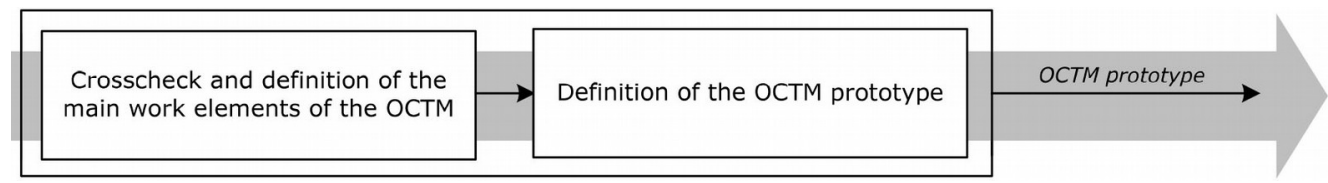

Figure 7. Workflow of OCTM prototype definition

\section{Results and Discussion}

\subsection{Work Elements Definition}

According to the experts, an OCTM focused on achieving a HPO should contain and somehow develop up to ten working elements (see Table 2).

Main working elements of the Organizational Culture Transformation Model

\begin{tabular}{|l|l|}
\hline 1. Ownership & 6. Common vision \\
\hline 2. Involvement & 7. People and team development \\
\hline 3. Change management & 8. Communication \\
\hline 4. Recognition & 9. Continuous improvement \\
\hline 5. Leadership & 10. Survey \\
\hline
\end{tabular}

Table 2. Main OCTM working elements based on work environment point of view 
According to the experts, the OCTM should have some impact on these ten working elements; consequently, the Culture of the Organization will evolve towards a state of HPO.

\subsection{Scientific Visualization and Crosscheck with Main Working Elements}

The query found 4,639 documents published from 1981 to 2020 ( $25^{\text {th }}$ July) concerning Organizational Culture. Through the analysis of what the scientific community has published, it can be seen that Organizational Culture takes on special relevance at the beginning of the $21^{\text {st }}$ century, the moment when the scientific community begins to contribute in an increasing, continuous manner until the present day (see Figure 8).

Through the analysis and subsequent visualization of the top 50 authors' keyword co-occurrence of documents published in the last six years (from 2015 to $25^{\text {th }}$ July 2020), it is possible to obtain the latest main concepts related to Organizational Culture according to the scientific community (see Figure 9), which will be used to crosscheck elements defined by experts, as explained previously.

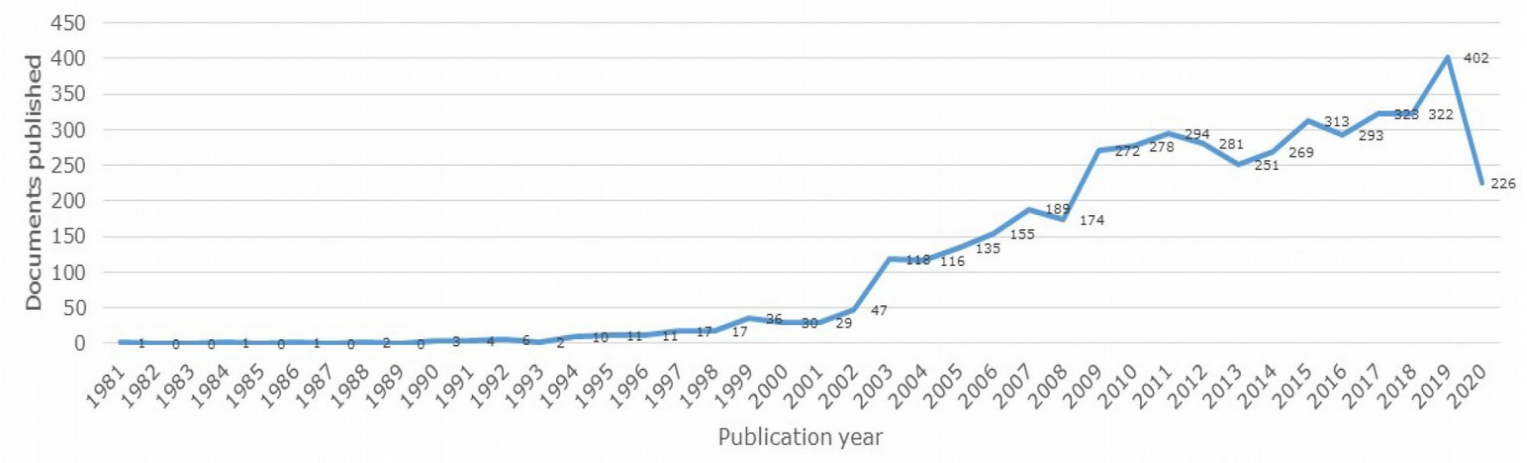

Figure 8. Annual publications in Organizational Culture from 1981 to 2020 (25 $5^{\text {th }}$ July)

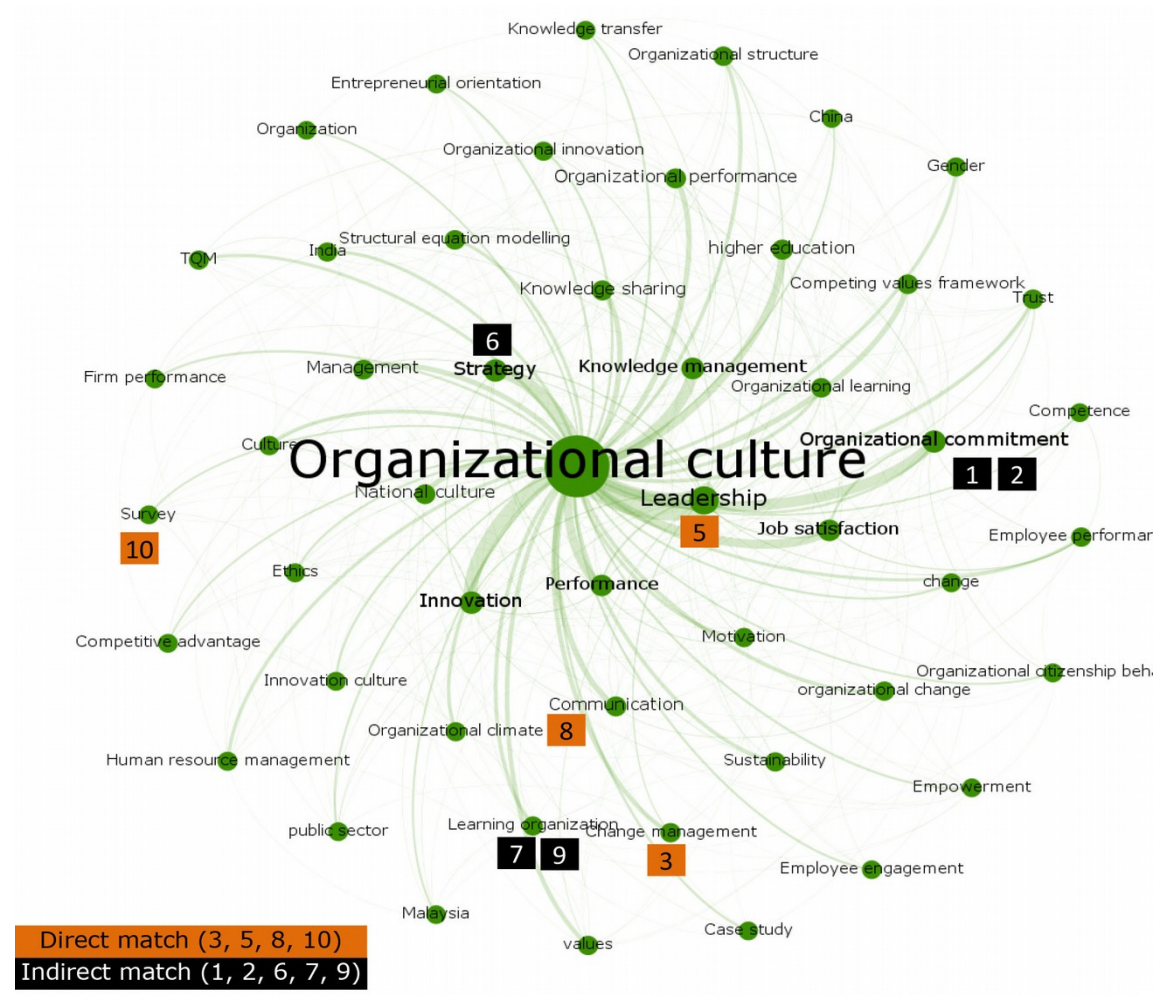

Figure 9. Networks of top 50 authors' keyword co-occurrence on Organizational Culture 
According to Figure 9, as many as nine of the ten elements that experts defined as basic for the OCTM are directly or indirectly cited, with only the "Reward" element remaining uncited. However, upon further reading and studying of the most important documents in the last six years, namely those most cited (see Table 3), it can be concluded that Reward \& Recognition is also a necessary element when the authors of these articles discuss Organizational Culture (Ahammad, Tarba, Liu \& Glaister, 2016; Bortolotti et al., 2015; Chang \& Lin, 2015; Valmohammadi \& Roshanzamir, 2015).

\begin{tabular}{|c|c|c|c|c|c|c|c|}
\hline $\mathrm{TC}$ & Title & Year & Authors & Affiliations & Country & Source & Author Keywords \\
\hline \multirow{5}{*}{225} & \multirow{5}{*}{$\begin{array}{l}\text { Successful lean } \\
\text { implementation: } \\
\text { Organizational } \\
\text { culture and soft } \\
\text { lean practices }\end{array}$} & \multirow{5}{*}{2015} & \multirow{3}{*}{ Bortolotti, T. } & \multirow{3}{*}{$\begin{array}{l}\text { Swansea } \\
\text { University }\end{array}$} & \multirow{3}{*}{$\begin{array}{l}\text { United } \\
\text { Kingdom }\end{array}$} & \multirow{5}{*}{$\begin{array}{l}\text { International } \\
\text { Journal of } \\
\text { Production } \\
\text { Economics }\end{array}$} & $\begin{array}{l}\text { High performance } \\
\text { manufacturing }\end{array}$ \\
\hline & & & & & & & Lean management \\
\hline & & & & & & & Multi-group analysis \\
\hline & & & Boscari, S. & University of & & & $\begin{array}{l}\text { Operational } \\
\text { performance }\end{array}$ \\
\hline & & & Danese, P. & Padova & Italy & & $\begin{array}{l}\text { Organizational } \\
\text { culture }\end{array}$ \\
\hline \multirow{6}{*}{110} & \multirow{6}{*}{$\begin{array}{l}\text { Knowledge } \\
\text { transfer and } \\
\text { cross-border } \\
\text { acquisition } \\
\text { performance: } \\
\text { The impact of } \\
\text { cultural distance } \\
\text { and employee } \\
\text { retention }\end{array}$} & \multirow{6}{*}{2016} & Ahammad, M.F. & $\begin{array}{l}\text { Nottingham } \\
\text { Trent } \\
\text { University }\end{array}$ & \multirow{6}{*}{$\begin{array}{l}\text { United } \\
\text { Kingdom }\end{array}$} & \multirow{6}{*}{$\begin{array}{l}\text { International } \\
\text { Business Review }\end{array}$} & $\begin{array}{l}\text { Cross-border } \\
\text { acquisition }\end{array}$ \\
\hline & & & Tarba, S.Y. & $\begin{array}{l}\text { The University } \\
\text { of Sheffield }\end{array}$ & & & Employee retention \\
\hline & & & Liu, Y. & $\begin{array}{l}\text { The University } \\
\text { of Kent }\end{array}$ & & & Knowledge transfer \\
\hline & & & \multirow{3}{*}{ Glaister, K.W. } & \multirow{3}{*}{$\begin{array}{l}\text { University of } \\
\text { Warwick }\end{array}$} & & & $\begin{array}{l}\text { National cultural } \\
\text { distance }\end{array}$ \\
\hline & & & & & & & $\begin{array}{l}\text { Organizational } \\
\text { culture differences }\end{array}$ \\
\hline & & & & & & & Performance \\
\hline \multirow{3}{*}{93} & \multirow{3}{*}{$\begin{array}{l}\text { Studying the } \\
\text { links between } \\
\text { organizational } \\
\text { culture, } \\
\text { innovation, and } \\
\text { performance in } \\
\text { Spanish } \\
\text { companies }\end{array}$} & \multirow{3}{*}{2016} & Naranjo, J.C. & $\begin{array}{l}\text { Universidad } \\
\text { Nacional de } \\
\text { Colombia }\end{array}$ & Colombia & \multirow{3}{*}{$\begin{array}{l}\text { Revista } \\
\text { Latinoamericana } \\
\text { de Psicologia }\end{array}$} & Innovation \\
\hline & & & Jiménez, D. & Universidad & & & $\begin{array}{l}\text { Organizational } \\
\text { culture }\end{array}$ \\
\hline & & & Sanz, R. & de Murcia & Spain & & Performance \\
\hline \multirow{2}{*}{92} & \multirow{2}{*}{$\begin{array}{l}\text { The role of } \\
\text { organizational } \\
\text { culture in the } \\
\text { knowledge } \\
\text { management } \\
\text { process }\end{array}$} & \multirow{2}{*}{2015} & Chang, C.L. & $\begin{array}{l}\text { National } \\
\text { Pingtung } \\
\text { University }\end{array}$ & \multirow{2}{*}{ Taiwan } & \multirow{2}{*}{$\begin{array}{l}\text { Journal of } \\
\text { Knowledge } \\
\text { Management }\end{array}$} & $\begin{array}{l}\text { Knowledge } \\
\text { management }\end{array}$ \\
\hline & & & Lin, T.C. & $\begin{array}{l}\text { National Sun } \\
\text { Yat-Sen } \\
\text { University }\end{array}$ & & & $\begin{array}{l}\text { Organizational } \\
\text { culture }\end{array}$ \\
\hline \multirow{5}{*}{92} & \multirow{5}{*}{$\begin{array}{l}\text { The guidelines } \\
\text { of } \\
\text { improvement: } \\
\text { Relations } \\
\text { among } \\
\text { organizational } \\
\text { culture, TQM } \\
\text { and } \\
\text { performance }\end{array}$} & \multirow{5}{*}{2015} & Valmohammadi, C. & \multirow{5}{*}{$\begin{array}{l}\text { Islamic Azad } \\
\text { University- } \\
\text { South Tehran } \\
\text { Branch }\end{array}$} & \multirow{5}{*}{ Iran } & \multirow{5}{*}{$\begin{array}{l}\text { International } \\
\text { Journal of } \\
\text { Production } \\
\text { Economics }\end{array}$} & $\begin{array}{l}\text { Organizational } \\
\text { culture }\end{array}$ \\
\hline & & & \multirow{4}{*}{ Roshanzamir, S. } & & & & $\begin{array}{l}\text { Organizational } \\
\text { performance }\end{array}$ \\
\hline & & & & & & & $\begin{array}{l}\text { Pharmaceutical } \\
\text { industry }\end{array}$ \\
\hline & & & & & & & $\begin{array}{l}\text { Structural equation } \\
\text { modeling (SEM) }\end{array}$ \\
\hline & & & & & & & $\begin{array}{l}\text { Total quality } \\
\text { management (TQM) }\end{array}$ \\
\hline
\end{tabular}




\begin{tabular}{|c|c|c|c|c|c|c|c|}
\hline TC & Title & Year & Authors & Affiliations & Country & Source & Author Keywords \\
\hline \multirow{6}{*}{83} & \multirow{6}{*}{$\begin{array}{l}\text { Understanding } \\
\text { counterproducti } \\
\text { ve knowledge } \\
\text { behavior: } \\
\text { antecedents and } \\
\text { consequences } \\
\text { of intra- } \\
\text { organizational } \\
\text { knowledge } \\
\text { hiding }\end{array}$} & \multirow{6}{*}{2016} & \multirow{3}{*}{ Serenko, A. } & \multirow{3}{*}{$\begin{array}{l}\text { Lakehead } \\
\text { University }\end{array}$} & \multirow{6}{*}{ Canada } & \multirow{6}{*}{$\begin{array}{l}\text { Journal of } \\
\text { Knowledge } \\
\text { Management }\end{array}$} & Employee turnover \\
\hline & & & & & & & $\begin{array}{l}\text { Facilitating } \\
\text { conditions }\end{array}$ \\
\hline & & & & & & & Knowledge hiding \\
\hline & & & \multirow{3}{*}{ Bontis, N. } & \multirow{3}{*}{$\begin{array}{l}\text { McMaster } \\
\text { University }\end{array}$} & & & Knowledge sharing \\
\hline & & & & & & & $\begin{array}{l}\text { Organizational } \\
\text { culture }\end{array}$ \\
\hline & & & & & & & Reciprocation \\
\hline \multirow{3}{*}{76} & \multirow{3}{*}{$\begin{array}{l}\text { Competing } \\
\text { through } \\
\text { employee } \\
\text { engagement: a } \\
\text { proposed } \\
\text { framework }\end{array}$} & \multirow{3}{*}{2016} & Al Mehrzi, N. & \multirow{3}{*}{$\begin{array}{l}\text { Abu Dhabi } \\
\text { University }\end{array}$} & \multirow{3}{*}{$\begin{array}{l}\text { United } \\
\text { Arab } \\
\text { Emirates }\end{array}$} & \multirow{3}{*}{$\begin{array}{l}\text { International } \\
\text { Journal of } \\
\text { Productivity and } \\
\text { Performance } \\
\text { Management }\end{array}$} & $\begin{array}{l}\text { Employee } \\
\text { engagement }\end{array}$ \\
\hline & & & \multirow[b]{2}{*}{ Singh, S.K. } & & & & Leadership \\
\hline & & & & & & & $\begin{array}{l}\text { Organizational } \\
\text { culture }\end{array}$ \\
\hline \multirow{5}{*}{73} & \multirow{5}{*}{$\begin{array}{l}\text { The impact of } \\
\text { organizational } \\
\text { culture on } \\
\text { supply chain } \\
\text { integration: A } \\
\text { contingency and } \\
\text { configuration } \\
\text { approach }\end{array}$} & \multirow{5}{*}{2015} & Cao, Z. & $\begin{array}{l}\text { Xi'an Jiaotong } \\
\text { University }\end{array}$ & \multirow{5}{*}{ China } & \multirow{5}{*}{$\begin{array}{l}\text { Supply Chain } \\
\text { Management }\end{array}$} & $\begin{array}{l}\text { Competing value } \\
\text { framework }\end{array}$ \\
\hline & & & Huo, B. & $\begin{array}{l}\text { Zhejiang } \\
\text { University }\end{array}$ & & & Configuration \\
\hline & & & Li, Y. & $\begin{array}{l}\text { Shanghai Jiao } \\
\text { Tong } \\
\text { University }\end{array}$ & & & Contingency \\
\hline & & & \multirow[t]{2}{*}{ Zhao, X. } & $\begin{array}{l}\text { China-Europe } \\
\text { International } \\
\text { Business } \\
\text { School } \\
\text { (CEIBS) }\end{array}$ & & & $\begin{array}{l}\text { Organizational } \\
\text { culture }\end{array}$ \\
\hline & & & & $\begin{array}{l}\text { South China } \\
\text { University of } \\
\text { Technology }\end{array}$ & & & $\begin{array}{l}\text { Supply chain } \\
\text { integration }\end{array}$ \\
\hline \multirow{5}{*}{71} & \multirow{5}{*}{$\begin{array}{l}\text { Sources of } \\
\text { alliance partner } \\
\text { trustworthiness: } \\
\text { Integrating } \\
\text { calculative and } \\
\text { relational } \\
\text { perspectives }\end{array}$} & \multirow{5}{*}{2015} & \multirow{2}{*}{ Schilke, O. } & \multirow{2}{*}{$\begin{array}{l}\text { University of } \\
\text { California }\end{array}$} & \multirow{5}{*}{$\begin{array}{l}\text { United } \\
\text { States }\end{array}$} & \multirow{5}{*}{$\begin{array}{l}\text { Strategic } \\
\text { Management } \\
\text { Journal }\end{array}$} & Alliances \\
\hline & & & & & & & Contracts \\
\hline & & & \multirow{3}{*}{ Cook, K.S. } & \multirow{3}{*}{$\begin{array}{l}\text { Stanford } \\
\text { University }\end{array}$} & & & $\begin{array}{l}\text { Interorganizational } \\
\text { relationships }\end{array}$ \\
\hline & & & & & & & $\begin{array}{l}\text { Organizational } \\
\text { culture }\end{array}$ \\
\hline & & & & & & & Trust \\
\hline \multirow{6}{*}{68} & & & & & & & Big data \\
\hline & & & Alharthi, A. & $\begin{array}{l}\text { Abu Dhabi } \\
\text { University }\end{array}$ & $\begin{array}{l}\text { United } \\
\text { Arab }\end{array}$ & & $\begin{array}{l}\text { Big data } \\
\text { infrastructure }\end{array}$ \\
\hline & $\begin{array}{l}\text { Addressing } \\
\text { barriers to big }\end{array}$ & 2017 & & & Emirates & Business & $\begin{array}{l}\text { Competitive } \\
\text { advantage }\end{array}$ \\
\hline & data & & & & & Horrzons & Data privacy \\
\hline & & & Krotov, V. & Murray State & United & & Hadoop \\
\hline & & & Bowman, M. & University & States & & $\begin{array}{l}\text { Organizational } \\
\text { culture }\end{array}$ \\
\hline
\end{tabular}

Table 3. The ten most cited documents in the period from 2015 to $17^{\text {th }}$ September 2020 


\subsection{Prototype of the Organizational Culture Transformation Model}

Based on the elements defined by the experts and the contributions of the scientific community, the first OCTM prototype is defined as follows (see Figure 10).

In the center, we have the HPO (see Figure 11), the core concept that defines the new organization resulting from the implementation and the purpose of the Model. As explained previously, in a High Performance Organization the capabilities of each individual within the organization are respected and developed, there is a productive use of the diversity and the operations are always principle based, furthermore, a clear vision exists and $100 \%$ of the organization is engaged and committed to achieving such, always working as a team, so they are continuously improving through a Zero Loss Mindset (Waal, 2008).

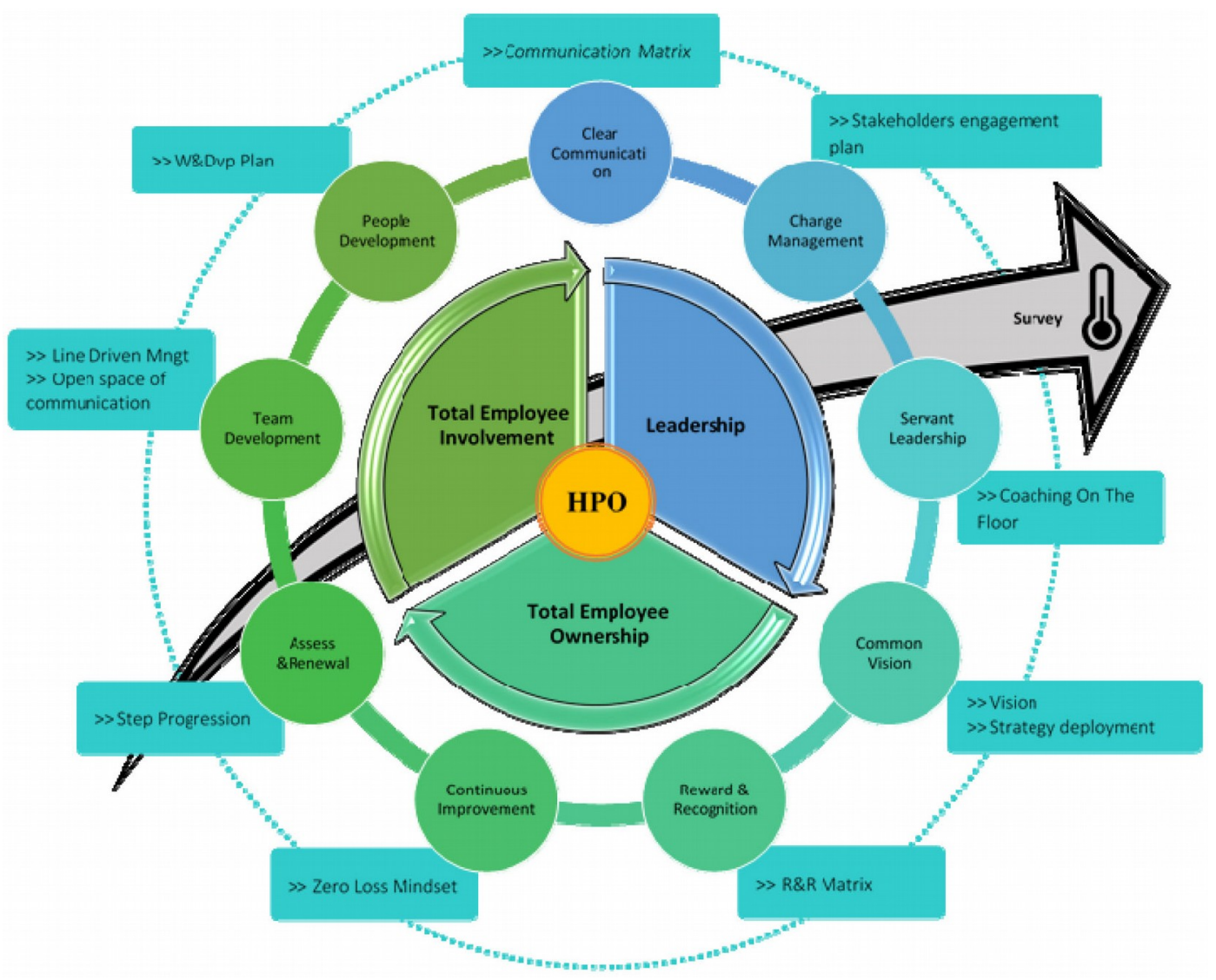

Figure 10. OCTM Prototype

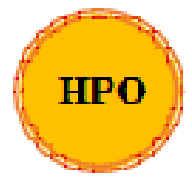

Figure 11. Core concept of the model

Around the central core and as the first layer, there are the three Design elements for HPO, being the facilitators for its achievement: Total Employee Ownership (TEO), Total Employee Involvement (TEI) and Leadership (see Figure 12).

An HPO requires a high level of ownership from each individual in order to involve them in achieving global targets, and for which a specific type of leadership is needed to enable both.

Next, above the first layer, is the Performing Element layer, containing the first elements that can be managed by choice (see Figure 13). 
It is in this layer where different tools will have an impact on the organization, in such a way that the effect reaches the central core or HPO, through TEO, TEI and Leadership. There are nine Performing Elements: Clear Communication, Change Management, Servant Leadership, Common Vision, Reward \& Recognition, Continuous Improvement, Assess \& Renewal, Team Development and People Development.

The third and last layer is the transform tools layer (see Figure 14). Those tools will be applied and used purposely in order to adapt each of the nine Performing Elements towards HPO. Each tool is mainly related to a specific performing element; however, the proposed Model is an integrated model, so it is not possible to view its elements as isolated work blocks.

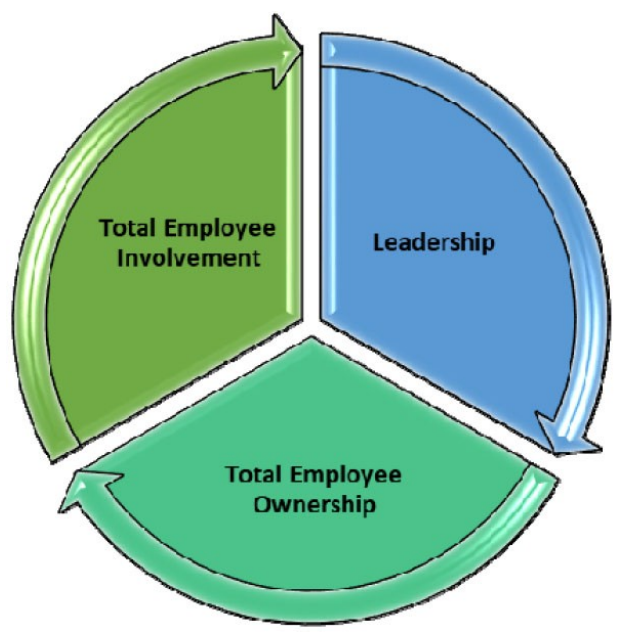

Figure 12. Design Elements layer

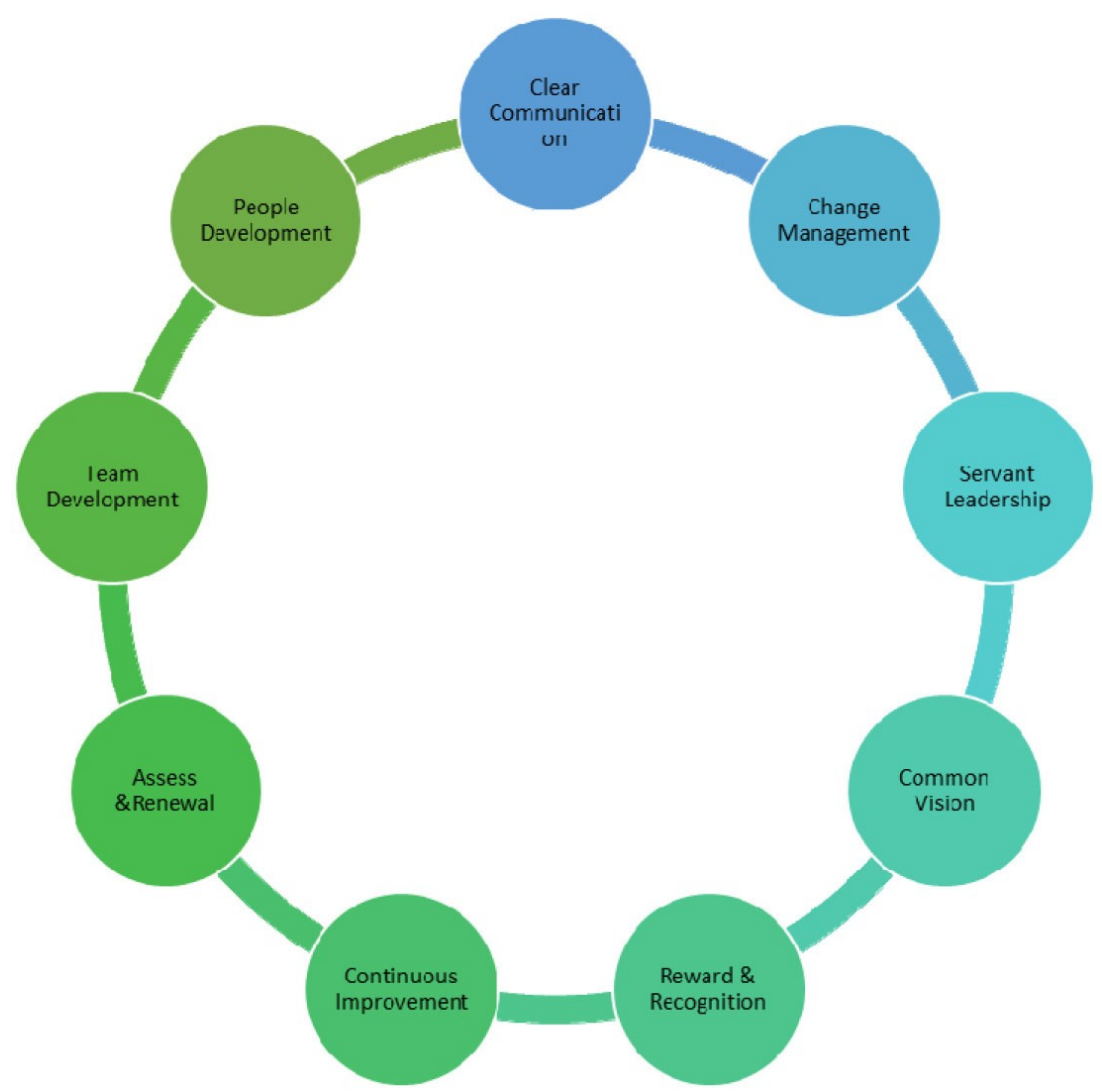

Figure 13. Performing Elements layer 
As an integrated model, all working tools are inter-related and modifying any of them, even slightly, will have an effect on all the Performing Elements, and consequently, also on the central nucleus. This fact makes it necessary to have a tool for measuring the Organizational Culture, in such a way that there is a continuous diagnosis being able to react accordingly by making the appropriate decisions. The last element is thus defined: Survey (see Figure 15).

An explanation of each tool is shown below in order to understand the tool itself, as well as its applicability and expected effects. It is important to remember the scope of the tools, namely to have an impact on the nine performing elements, in order to deploy the three Performing Elements and thus achieve the HPO.

As seen in Figure 14 and Figure 15, there are twelve tools:

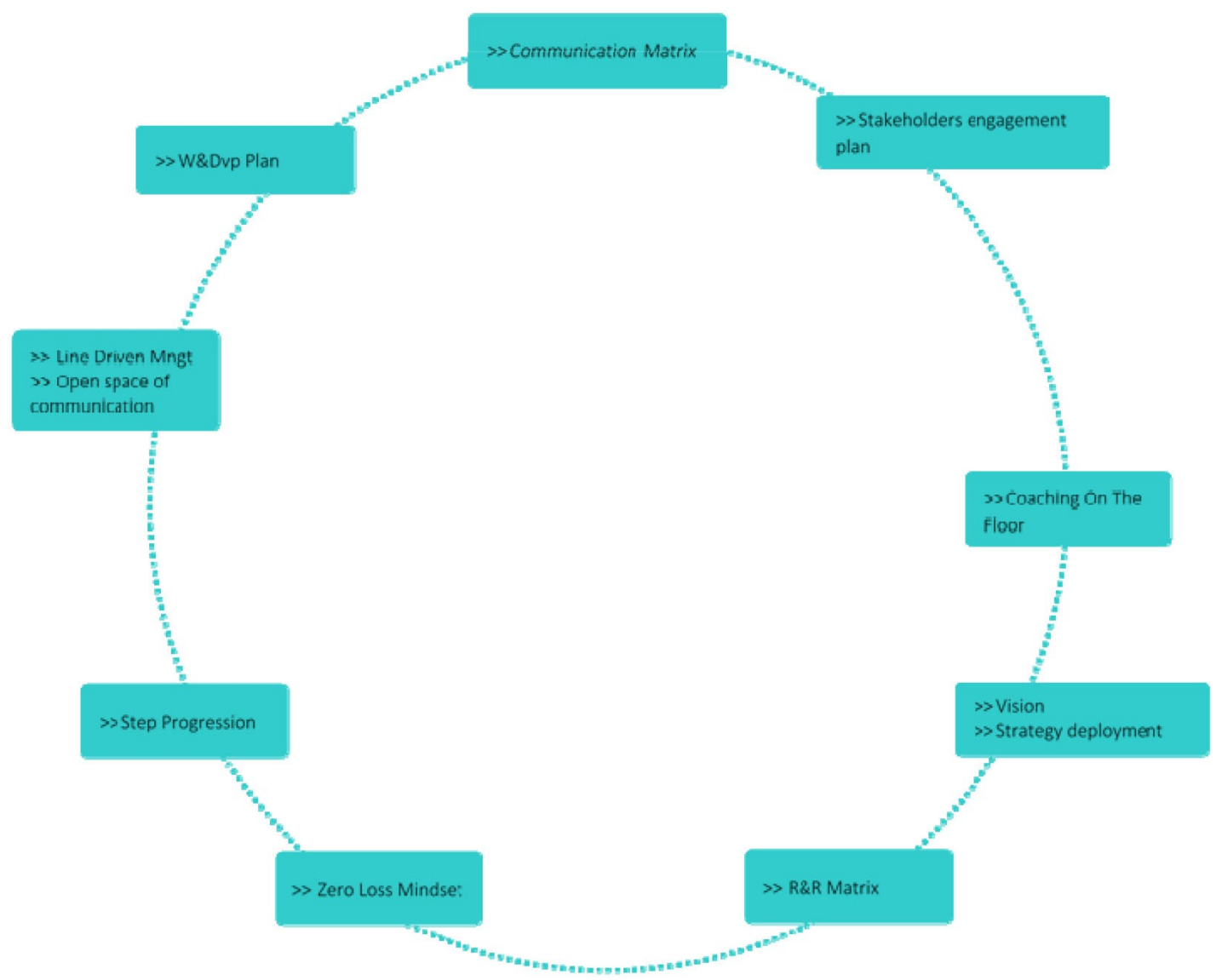

Figure 14. Working Tools layer

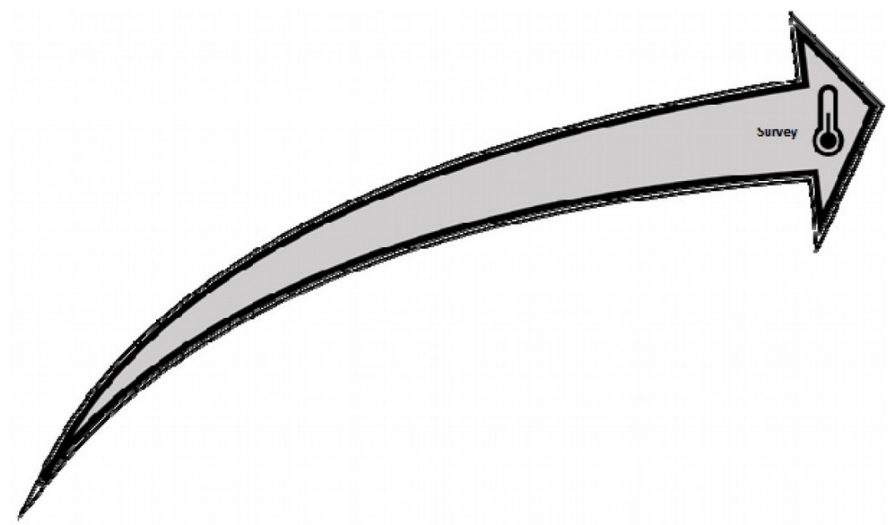

Figure 15. Survey 


\subsubsection{Clear Communication > Communication Matrix}

As the model is focused on transforming Organizational Culture, it is necessary to understand that the organization will inevitably face big changes, and it will be necessary to keep the whole organization regularly informed in terms of the journey, the successes and achieved milestones (Asamu, 2014).

The aim is to prevent resistance to change and, to this end, senior management has to define, what, where, how, when and to whom will be communicated through a communication matrix, which will enable common unique speech, thus eliminating possible noise (Elving, 2005). Nowadays digital platforms can be used to harness considerable potential.

\subsubsection{Change Management $>$ Stakeholder Engagement Plan}

To make the transformation journey happen through a successful change management process and prior to taking any step, a stakeholder engagement plan should be defined (AlMehrzi \& Singh, 2016).

Stakeholders, understood as the key figures and roles of all the value chain (from suppliers to customers) which, due to their relevance, need to be monitored in detail in order to adapt to their needs, questions, fears, barriers and limiting beliefs as best as possible.

Based on a model developed in the 1960s by Elisabeth Kuber-Ross to explain the grieving process, the change curve is a widely utilized method to monitor the reactions to significant changes, so it would be an appropriate tool to use for the definition of the stakeholders engagement plan.

The stage at which each stakeholder is located will be identified and senior management will prepare a personalized plan to move each of the stakeholders from one stage to the next.

The plan will define the current stage, an action plan and whoever is responsible for each stakeholder, this has to be updated frequently to monitor how the journey is evolving.

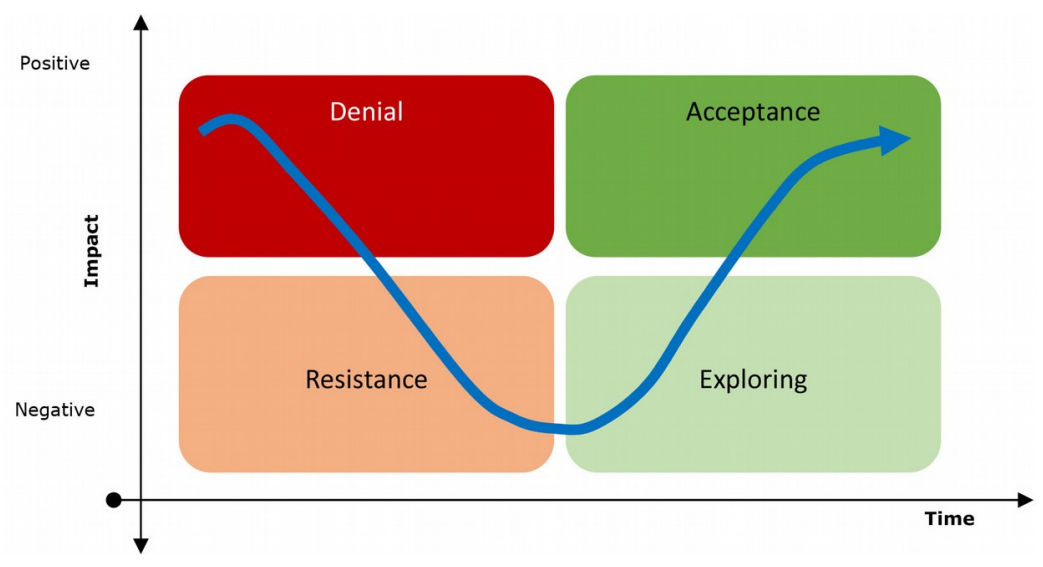

Figure 16. Change Curve

\subsubsection{Servant Leadership $>$ Coaching on the floor}

As explained previously, an HPO requires a high level of ownership from each individual in order to involve them in achieving global targets, which produces a servant leadership style focused on developing the necessary capabilities of each individual within the organization.

$100 \%$ of the people in the organization have to be developed, however and due to their direct impact when adding value, machine operators are of special importance. For this end, all of the organization's leaders need to possess coaching skills.

Coaching will focus on continues improvement through elimination of losses, so it is not possible to do this effectively if it does not happen on the shop floor, working alongside the machine operator, asking them questions about problems in their daily routine, trying to provide them with a solution and, at the same time, implanting new 
skills that will enable people to continue to detect losses constantly and, in parallel, consequently develop their ownership and involvement.

To deploy servant leadership, coaching skills are essential, so as with other tools, first and foremost, a diagnosis of current skills is needed and, if these are found to be lacking, then training should be carried out.

In addition to coaching skills, leaders also need time on the shop floor to deploy those skills effectively. That is why a minimum of two hours per day shop-floor coaching time has to be established throughout the organization and during which there should be no meetings scheduled, no phone calls, no rest periods, no coffee breaks... just leaders coaching operators at the machine.

\subsubsection{Common Vision > Vision}

It is not possible to generate ownership in the organization if there is no common vision to engage with (Serenko \& Bontis, 2016).

That is why senior management needs to create a vision for the future, based on the business needs as a roadmap. The vision has to be shared within the organization in such a way that $100 \%$ of the people are aware of the aims of the team commitment, so they begin thinking how each one can individually contribute to this vision.

The best way to remember the vision is to make it visual everywhere. A good way to reinforce people's ownership and engagement is to ask to them to create a picture which represents the common vision, then asking the entire organization to vote for the best picture.

The chosen picture will be posted everywhere in the factory and at the end of the whole process everybody will have a clear idea of the organization's vision.

\subsubsection{Common Vision > Strategy Deployment}

Without a common vision, there is no strategy and it is impossible to generate an effective personal ownership and involvement. However, having a vision does not necessarily mean that it is correct deployment (Alharthi, Krotov \& Bowman, 2017).

Once a clear vision is created, the next step is to deploy the strategy within the organization. The objective is to create a link between the global vision with individual contributions.

To this end, starting from top management down to machine operators, each level of the organization has to create a plan concerning the items to develop in order to define the contribution to the global vision, in such a way that by adding all individual contributions, business needs will be reached as a guarantee of the future.

At the same time, once effective deployment has been made through specific plans, everybody will have a clear vision about their personal contribution to the organization, creating ownership and involving the whole organization in achieving the global vision.

\subsubsection{Reward \& Recognition > Reward \& Recognition Matrix}

As a facilitator of the transformation journey, it is necessary to reward and recognize expected achievements and behaviors.

Reward and recognition have been identified as strong motivational tools to boost employees' drive towards accomplishing organizational goals and objectives (Amoatemaa \& Kyeremeh, 2016) To make an HPO happen, employees have to adopt defined behaviors (Hussain, Khaliq, Nisar, Kamboh \& Ali, 2019), consequently, exactly what behaviors and achievements will be rewarded or recognized, by whom and how, has to be determined in advance by senior management in the form of a Reward and Recognition matrix. Different reward and recognition time frames are needed, from daily, to quarterly or yearly.

As with the rest of the tools, the matrix has to be shared within the entire organization, sending a clear message as to what is expected from people in terms of behavior and achievement. 
Once the Reward and Recognition matrix has been developed and deployed, senior management need to lead by example and be rigorous with its implementation. Whatever leaders reward or recognize will flourish and grow exponentially.

\subsubsection{Continuous improvement $>$ Zero Loss Mindset}

In line with Waal's definition (Waal, 2008), HPO implies a Zero Loss Mindset, so a continuous improvement culture should be well established within the organization.

Based on the founder of the Toyota Production System, there are seven core losses in production: Overproduction, Waiting, Unnecessary motions, Transporting, Overprocessing, Unnecessary inventory and Defects (Gram, 2013; Ohno, 1988).

Each individual in the organization must continuously eliminate those losses in their areas of responsibility. A rigorous implementation of the continuous improvement mindset will generate the need of new capabilities in the organization in order to identify and set new losses and, as a consequence, ownership and involvement will grow and grow.

\subsubsection{Assess \& Renewal > Step progression}

Like every journey, to ensure that the proper path is being taken, the transformation of the Organizational Culture will also need to establish certain milestones to assure proper deployment towards the HPO.

Senior Management should define a four-step progression, determining the results to be achieved and the behaviors deployed at each step. Each step will be increasingly challenging and, consequently, require greater skill sets for people development.

The last step will mean that the organization is an HPO.

\subsubsection{Team Development $>$ Line Driven Management}

The proposed model is a line driven management-based model. Thus, everything happens in the line and the line is accountable for all the results, not only production results but also safety, quality and cost.

Line driven management is considered as key factor for the development of ownership and involvement of people within the organization. If the safety department is accountable for safety results, this will not help to create ownership with the machine operators and consequently they will not be involved in improving safety results.

That is why production area leaders should be properly selected, based on their accountability, servant leadership and people development skills.

The rest of the functional departments, such as safety, quality, cost accounting, environment... will evolve towards a role of capability injectors. As experts in their respective subjects, each department will inject expertise into the line through standards, enabling people's capabilities to grow continuously.

\subsubsection{Team Development > Open Space of Communication}

Traditionally, every organization usually has a Human Resources department to take care of individuals. Unfortunately, there is no one to take care of the teams, rather inexplicable when we consider that teamwork is the essence of all organizations.

Teams are created, grow, evolve and occasionally disappear. Someone has to take care of each stage, in order to optimize team performance.

During the team building, it is necessary to clarify the role and expectations of each team member, as well as establishing how the decision-making process will be carried out and interaction rules between the team members have to be agreed.

At the same time, each team needs to create a mission as a team, and fully aligned with the global vision. 
Each team needs to schedule weekly time-slots for themselves, to discuss team member moods, feelings and emotions, which will reinforce ties between members and result in better deployment and performance.

On a regular basis, a member of senior management should assess the effectiveness of each team, sitting in on the weekly meetings and checking whether interaction between team members is as expected in order to achieve results.

\subsubsection{People Development $>$ Work \& Development Plan}

People development becomes transcendental when speaking about HPO, thus, and as suggested by the term itself, for an HPO the capabilities of each individual within the organization are respected and developed.

The model proposes development driven by ownership and loss elimination. To this end, each machine operator will be owner of a part of the machine where they work and will be responsible for eliminating losses on that specific part of the equipment.

Loss elimination targets will be established in line with the global vison and will be each operator's individual contribution to it.

Thus, the model will generate ownership (they are owner of a part of the machine), involvement (they focus on achieving their individual loss elimination targets), engagement (they are aligned with the global vision through their individual contribution), capability injection by functional experts (they will need new capabilities to continue eliminating new losses) and continuous improvement mindset (they are always eliminating losses through root cause analysis).

All this should be centralized in an individual Work and Development plan, defining the organization of the following items for each member: Equipment part that is owned, global vision, loss elimination targets as individual contribution and capability injection needed in order to achieve these.

Each machine operator should regularly review their plan with their leader in order to monitor and ensure that goals are being met.

\subsubsection{Survey}

As explained, the proposed Model is a multilayer, integrated model, so it is not possible to view its elements as isolated work blocks. As an integrated model, all working tools are inter-related and modifying any of them, even slightly, will have an effect on others, and consequently, also on the central core.

Thus, it is necessary to have a tool for measuring Organizational Culture, in such a way that there is ongoing diagnosis, making it possible to react accordingly by making the appropriate decisions.

The model proposes a survey based on 23 questions (see Table 4), which are scored from "1: Strongly disagree" to "5: Strongly agree".

The survey should be completed regularly (at least once per year) by operators and, based on the results, each leader should prepare a plan to continuously improve on this score.

\begin{tabular}{|r|l|}
\hline 1. & In my team I have a clear role which allows me to contribute to my best potential \\
\hline 2. & I feel my unique background, style and viewpoints are valued and leveraged by others, including my peers and leaders \\
\hline 3. & I seek out people providing me with honest and candid feedback in order to continuously improve \\
\hline 4. & My Leader spends enough time with me to know me as a person \\
\hline 5. & I own a part of equipment and I am accountable for the results \\
\hline 6. & I am appropriately involved in decisions that affect my work \\
\hline 7. & I am recognized and rewarded for my contribution to the business \\
\hline 8. & In my organization nothing of what we do is worth an injury \\
\hline 9. & I have a work plan that has a clear link to the business needs (Vision) \\
\hline
\end{tabular}




\begin{tabular}{|l|l|}
\hline 10. & I believe my organization is on the right track to deliver the desired business results \\
\hline 11. & I am accountable for the tracking and reporting of my results. \\
\hline 12. & I take initiative to come up with better ways of doing things to eliminate any possible loss. \\
\hline 13. & I receive adequate information to understand the environment in which we do business in order to perform my role \\
\hline 14. & $\begin{array}{l}\text { My team proactively responds to any changes in production and initiative projects, which are driven by external market } \\
\text { needs. }\end{array}$ \\
\hline 15. & $\begin{array}{l}\text { I proactively take responsibility for my own learning and development (e.g., I subscribe to trainings, seek out } \\
\text { developmental experiences, and ask for coaching). }\end{array}$ \\
\hline 16. & I receive the training and coaching necessary to achieve my goals. \\
\hline 17. & My Leader roles model the expected behaviors. \\
\hline 18. & My team uses benchmarking and re-application both internally and externally to improve its performance. \\
\hline 19. & My team learns from both its successes and failures. \\
\hline 20. & My team and I are rewarded to find root causes to problems rather than quick fixes. \\
\hline 21. & $\begin{array}{l}\text { In my experience, collaboration with other teams, departments and functions is effective and contributes to strong } \\
\text { business results. }\end{array}$ \\
\hline 22. & $\begin{array}{l}\text { My team and organization work closely and effectively with customers, suppliers and other outside relevant } \\
\text { organizations. }\end{array}$ \\
\hline 23. & I am part of a team that has the capability to make all relevant decisions to achieve its business objective. \\
\hline
\end{tabular}

Table 4. Organizational Culture Survey

\section{Conclusions and Future Lines of Research}

The design of OCTM, acquires special relevance and significance in the current progressively globalized framework, where markets are increasingly competitive, dynamic, aggressive and changing. A fact that is contrasted with the growing interest of scientific production in the analyzed field. Through this work, a prototype of a model focused on achieving an HPO has been designed with the support of experts and documents provided by the scientific community. From here in, and as future lines of action, the next step should be to conduct a pilot test of the model in an industrial environment.

The company where the research has been developed has shown interest in continuing to support the research work, so the pilot test will be carried out in one of its manufacturing departments.

\section{Acknowledgement}

Thanks to the company where the research has been developed, for the support offered to perfrom it, and making all of its knowledge available for the study.

\section{Declaration of Conflicting Interests}

The authors declared no potential conflicts of interest with respect to the research, authorship, and/or publication of this article.

\section{Funding}

The authors received no financial support for the research, authorship. and/or publication of this article.

\section{References}

Abdullah, N.H., Shamsuddin, A., Wahab, E., \& Hamid, N.A.A. (2014). The Relationship between Organizational Culture and Product Innovativeness. Procedia - Social and Behavioral Sciences, 129, 140-147.

https://doi.org/10.1016/j.sbspro.2014.03.659 
Ahammad, M.F., Tarba, S.Y., Liu, Y., \& Glaister, K.W. (2016). Knowledge transfer and cross-border acquisition performance: The impact of cultural distance and employee retention. International Business Review, 25(1), 66-75.

Alharthi, A., Krotov, V., \& Bowman, M. (2017). Addressing barriers to big data. Business Horizons, 60(3), 285-292. https://doi.org/10.1016/j.bushor.2017.01.002

AlMehrzi, N., \& Singh, S. (2016). Competing through employee engagement: a proposed framework. International Journal of Productivity and Performance Management, 65(6), 831-843. https://doi.org/10.1108/IJPPM-02-2016-0037

Alvarez-Meaza, I., Zarrabeitia-Bilbao, E., Rio-Belver, R.M., \& Garechana-Anacabe, G. (2020). Fuel-cell electric vehicles: Plotting a scientific and technological knowledge map. Sustainability, 12(6).

https://doi.org/10.3390/su12062334

Amoatemaa, A.S., \& Kyeremeh, D.D. (2016). Making employee recognition a tool for achieving improved performance: implication for ghanaian universities. Journal of Education and Practice, 7(34), 46-52. https://files.eric.ed.gov/fulltext/EJ1126683.pdf

Asamu, F. (2014). The Impact of Communication on Workers' Performance in Selected Organisations in Lagos State, Nigeria. IOSR Journal of Humanities and Social Science, 19(8), 75-82. https://doi.org/10.9790/0837-19827582

Azanza, G., \& Moriano, J.A. (2013). Authentic leadership and organizational culture as drivers of employees' job satisfaction. Journal of Work and Organizational Psychology. 29(2), 45-50.

Bastian, M., Heimann, S., \& Jacomy, M. (2009). Gephi: an open source software for exploring and manipulating networks. International AAAI Conference on Weblogs and Social Media.

Belias, D., Koustelios, A., Vairaktarakis, G., \& Sdrolias, L. (2015). Organizational Culture and Job Satisfaction of Greek Banking Institutions. Procedia - Social and Behavioral Sciences, 175, 314-323.

https://doi.org/10.1016/j.sbspro.2015.01.1206

Bortolotti, T., Boscari, S., \& Danese, P. (2015). Successful lean implementation: Organizational culture and soft lean practices. International Journal of Production Economics, 160, 182-201. https://doi.org/10.1016/j.ijpe.2014.10.013

Capacity4dev. (2015). Evaluation methodological approach: Panel de expertos. https://europa.eu/capacity4dev/evaluation guidelines/wiki/panel-de-expertos

Chang, C.L.H, \& Lin, T.C. (2015). The role of organizational culture in the knowledge management process. Journal of Knowledge Management, 19(3), 433-455. https://doi.org/10.1108/JKM-08-2014-0353

Chávez, J.J., \& Ibarra, J.P. (2016). Liderazgo y cambio cultural en la organización para la sustentabilidad Leadership and cultural change in the. TELOS. Revista de Estudios Interdisciplinarios En Ciencias Sociales, 18(1), 138-158.

Company of study (2019). Internal Company report 2019.

Contreras, A.B., \& Gómez, A. (2018). Determinar las características de la Cultura Organizacional Application of the Denison Questionnaires to determine the characteristics of Organizational Culture. Revista de Investigación Sigma (RIS), 59-86.

Cújar, A.C., Ramos, C.D., Hernández, H.E., \& López, J.M. (2013). Cultura organizacional: evolución en la medición. Estudios Gerenciales, 29(29), 350-355. www.elsevier.es/estudios gerenciales

Di Fabio, A., \& Peiró, J.M. (2018). Human capital sustainability leadership to promote sustainable development and healthy organizations: A new scale. Sustainability (Switzerland), 10(7). https://doi.org/10.3390/su10072413

Elsevier (2019). Scopus: Content Coverage Guide. https://www.elsevier.com/ data/assets/pdf file/0017/114533/Scopus GlobalResearch Factsheet2019 FINAL WEB.pd $\underline{f}$

Elving, W.J.L. (2005). The role of communication in organisational change. Corporate Communications, 10(2), 129-138. https://doi.org/10.1108/13563280510596943 
Felipe, C.M., Roldán, J.L., \& Leal-Rodríguez, A.L. (2017). Impact of Organizational Culture Values on Organizational Agility. Sustainability, 9(12), 2354. https://doi.org/10.3390/su9122354

Gephi (2019). Gephi - The Open Graph Viz. Platform. https://gephi.org/

Gram, M. (2013). A Systematic Methodology to Reduce Losses in Production with the Balanced Scorecard Approach. Manufacturing Science and Technology, 1(1), 12-22. https://doi.org/10.13189/mst.2013.010103

Hartnell, C.A., Ou, A.Y., \& Kinicki, A. (2011). Organizational culture and organizational effectiveness: A meta-analytic investigation of the competing values framework's theoretical suppositions. Journal of Applied Psychology, 96(4), 677-694. https://doi.org/10.1037/a0021987

Hussain, S.D., Khaliq, A., Nisar, Q.A., Kamboh, A.Z., \& Ali, S. (2019). Impact of Employees' Recognition, Rewards and Job Stress on Job Performance: Mediating Role of Perceived Organization Support. SEISENSE Journal of Management, 2(2), 25-37. https://doi.org/10.33215/sjom.vXiX.XX

Iljins, J., Skvarciany, V., \& Gaile-Sarkane, E. (2015). Impact of Organizational Culture on Organizational Climate During the Process of Change. Procedia - Social and Behavioral Sciences, 213, 944-950.

https://doi.org/10.1016/j.sbspro.2015.11.509

Lee, J.C., Shiue, Y.C., \& Chen, C.Y. (2016). Examining the impacts of organizational culture and top management support of knowledge sharing on the success of software process improvement. Computers in Human Behavior, 54, 462-474. https://doi.org/10.1016/j.chb.2015.08.030

Maish, E. (2004). Pautas Metodológicas Para La Realización De Estudios De Clima Organizacional. Gestión En El Tercer Milenio, 7(13), 87-91.

Ohno, T. (1988). Toyota Production System: Beyond large-scale production. Productity Press.

Sandoval, J.L. (2014). Los procesos de cambio organizacional y la generación de valor. Estudios Gerenciales, 30(131), 162-171. https://doi.org/10.1016/j.estger.2014.04.005

Schein, E.H. (2004). Organizational culture and leadership (3rd ed.). John Wiley \& Sons.

Serenko, A., \& Bontis, N. (2016). Understanding counterproductive knowledge behavior: antecedents and consequences of intra-organizational knowledge hiding. Journal of Knowledge Management, 20(6), 1199-1224. https://doi.org/10.1108/JKM-05-2016-0203

Valmohammadi, C., \& Roshanzamir, S. (2015). The guidelines of improvement: Relations among organizational culture, TQM and performance. International Journal of Production Economics, 164, 167-178.

https://doi.org/10.1016/j.ijpe.2014.12.028

VantagePoint. (2019). The VantagePoint. https://www.thevantagepoint.com/

Waal, A.A. (2008). The Secret of High Performance Organizations. Management Online Reviem, 1-10.

Journal of Industrial Engineering and Management, 2021 (www.jiem.org)

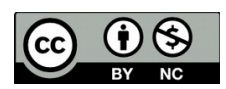

Article's contents are provided on an Attribution-Non Commercial 4.0 Creative commons International License. Readers are allowed to copy, distribute and communicate article's contents, provided the author's and Journal of Industrial Engineering and Management's names are included. It must not be used for commercial purposes. To see the complete license contents, please visit https://creativecommons.org/licenses/by-nc/4.0/. 